\title{
Effect of weather parameters on incidence of insect pests of cucumber in eastern Bihar
}

\author{
TAMOGHNA SAHA ${ }^{1}$, NITHYA CHANDRAN ${ }^{2}$, SUNIL KUMAR ${ }^{3}$ and KIRAN KUMARI ${ }^{1}$ \\ ${ }^{1}$ Department of Entomology, ${ }^{3}$ Department of Agronomy \\ Bihar Agricultural University, Sabour, Bhagalpur-813210, Bihar, India \\ ${ }^{2}$ Division of Entomology, Indian Agricultural Research Institute, New Delhi-110012 \\ Email ID: tamoghnasaha1984@gmail.com
}

\begin{abstract}
The insect-pests infestation in cucumber leads to severe injury to its' vegetative parts and fruits by epilachna beetle, red pumpkin beetle, whitefly, pumpkin caterpillar, leaf minerand fruit fly. The present investigation was taken upduring 2014 and 2015 to study the population dynamics of prevailing six insect-pests of cucumber and its natural enemies inrelation to weather parameters. The correlation studies between insect pests and weather parameters revealed that the melon fruit fly (Bactrocera cucurbitae Coquillett), epilachna beetle (Epilachna vigintioctopunctata Fabricius), red pumpkin beetle (Aulacophora foveicollisLucas), whitefly (Bemisia tabaci Gennadius), pumpkin caterpillar (Diaphania indica Saunders) and leaf miner (Liriomyza trifolii Burgess) showed significant positive correlation with maximum and minimum temperature, whereas negative and nonsignificant correlation with relative humidity and rainfall. The natural enemies such ascoccinellids and spiders showed significant positive correlation with maximum and minimum temperature, and non significant negative correlation with relative humidity and rainfall. Sunshine hour showed positive correlation with all the insect pests and natural enemies except epilachna beetle.
\end{abstract}

Key words : Insect pests, population dynamics, cucumber, climatic factors

Cucumber (Cucumis sativus L.) is an important vegetable crop and one of the most popular members of the Cucurbitaceae family. Like other cucurbits, cucumber is also being subjected to damage by wide array of insect pests' right from the initial stages of the crop toharvest of the products in India. The extent of loss caused by these dipteran flies is varying from 20 to 100 per cent depending upon cucurbit species and environmental conditions (Rai et al., 2014). The melon fruit fly, red pumpkin beetle (Aulacophora foveicollis Lucas) and epilachna beetle (Henosepilachna septima Dieke), leaf roller, green semilooper and white fly etc. are the most destructive pest of cucurbits (Barma and Jha, 2013;Khan et al., 2012; Krisha Kumar et al., 2006).

Keeping this in view, the present investigation was carried out on occurrence of melon fruit fly, epilachna beetle, red pumpkin beetle, leaf roller, leaf miner, whitefly, natural enemies (coccinellids and spiders) with abiotic factors to develop economical strategies of pest management.

\section{MATERIALS AND METHODS}

The present investigation was carried out during the summer season of 2014-15 and 2015-16 at Vegetable
Research Farm of Bihar Agricultural University, Sabour, Bhagalpur, Bihar (latitude $87^{\circ} 2^{\prime} 54^{\prime \prime}$, longitude $25^{\circ} 14^{\prime}$ $24 " \mathrm{~N}$, altitude $30 \mathrm{~m}$ a.s.1.).

The local variety of cucumber 'Varsha' was grown in a plot size $25 \mathrm{~m}^{2}(5 \mathrm{~m} \times 5 \mathrm{~m})$ with a plant spacing $100 \mathrm{~cm} \times$ $130 \mathrm{~cm}$. All agronomical practices were done to raise the crop excluding plant protection measures. Observations on pest incidence were taken at an interval of seven days at morning hours during the whole period of crop growing season. Direct count of all the developmental stages of the pests like epilachna beetle (grub and adult) and redpumpkin beetle (adult) were taken from randomly selected seven plants from each plot. For fruit fly, three bottle traps were installed at a distance of $50 \mathrm{~m}$ between the traps to avoid trap interference effect. These traps were charged with $0.4 \mathrm{ml}$ of cuelure and $1 \mathrm{ml}$ of dichlorovos at monthly and fortnightly intervals respectively. The fruit flies were collected at weekly intervals and identified to species level and recorded. For observation of pumpkin caterpillar and leaf miner, randomly tagged five vines per plot were selected and number of larvae per vine and no. of mines per vine were counted at weekly interval. The Bemisiatabaci (Gennadius) population was recorded 
Table 1: Enumeration of insect pests and natural enemies in cucumber

\begin{tabular}{|c|c|c|c|c|c|}
\hline Sl. no. & Scientific Name & $\begin{array}{l}\text { Common } \\
\text { Name }\end{array}$ & Family & Order & Remarks \\
\hline 1. & $\begin{array}{l}\text { Epilachna } \\
\text { vigintioctopunctata } \\
\text { (Fabricius) }\end{array}$ & $\begin{array}{l}\text { Hadda } \\
\text { beetle }\end{array}$ & Coccinellidae & Coleoptera & Foliage feeder \\
\hline 2. & $\begin{array}{l}\text { Aulacophora } \\
\text { foveicollis } \\
\text { (Lucas) }\end{array}$ & $\begin{array}{l}\text { Red pumpkin } \\
\text { beetle }\end{array}$ & Chrysomelidae & Coleoptera & Foliage and flower feeder \\
\hline 3. & $\begin{array}{l}\text { Diaphania indica } \\
\text { (Saunders) }\end{array}$ & $\begin{array}{l}\text { Pumpkin } \\
\text { caterpillar }\end{array}$ & Pyralidae & Lepidoptera & Foliage tender fruit feeder \\
\hline 4. & $\begin{array}{l}\text { Bactrocera } \\
\text { cucurbitae } \\
\text { (Coquillet) }\end{array}$ & Fruit fly & Tephritidae & Diptera & Damaging fruits \\
\hline 5. & $\begin{array}{l}\text { Bemisia tabaci } \\
\text { (Genn.) }\end{array}$ & Whitefly & Aleyrodidae & Hemiptera & Foliage feeder \\
\hline 6. & $\begin{array}{l}\text { Liriomyza } \\
\text { trifolii (Burgess) }\end{array}$ & Leaf miner & Agromyzidae & Diptera & Mining leaves \\
\hline & & & Natural enemies & & \\
\hline 1. & $\begin{array}{l}\text { i. Coccinella } \\
\text { septempunctata } \\
\text { ii. Menochilus } \\
\text { sexmaculata }\end{array}$ & Coccinellids & Coccinellidae & Coleoptera & Predator \\
\hline 2. & $\begin{array}{l}\text { i. Neoscona spp } \\
\text { ii. Oxyopes spp }\end{array}$ & Spiders & Araneidae & Araneae & Generalist Predator \\
\hline
\end{tabular}

by counting it at weekly interval on five tagged randomly selected plants by observing three compound leaves selected from different positions, i.e., bottom, middle and top of the plant in each replication. Regarding natural enemy (coccinellids Coccinella septempunctata L. and Menochilus sexmaculata Fabricius and spiders) is concerned, five vines per plot were selected and number of natural enemy was counted (Table 1).

Meteorological data viz., maximum and minimum temperature $\left({ }^{\circ} \mathrm{C}\right)$, rainfall $(\mathrm{mm})$, maximum and minimum relative humidity (\%) and sunshine hours were collected from the Department of Agronomy (Meteorology), Bihar Agricultural University, Sabour, Bhagalpur, Bihar. Correlation and regression were made between insect pests, trap catches and mean weather parameters.

\section{RESULTS AND DISCUSSION}

\section{Melon fruit fly (Bactrocera cucurbitae, Coq.)}

The pooled data of two years shows that the fruit fly
(Bactrocera cucurbitae, Coq.) occurred from third week of April to second and third week of June (Table 2). The peak (50 to 66 fruit fly/trap/week) population of fruit fly was recorded during May. Banerji et al. (2005) also reported that peak population of fruit fly was recorded on bitter gourd in West Bengal during summer followed by winter season. The melon fruit fly had significant positive correlation with both maximum $(\mathrm{r}=+0.623)$ and minimum $(\mathrm{r}=+0.632)$ temperature (Table 3 ) and non significant correlations with other parameters. Barma and Jha (2013) had also reported significant positive correlation with maximum and minimum temperature alongwith negatively significance with relative humidity.

\section{Red pumpkin beetle (Aulacophora foveicollis,Lucas)}

Red pumpkin beetle infestation was observed throughout the cropping period with highest population (2.80 to 3.40 adults/plant) during first week of May to first week of June (Table 2). Rathod and Borad (2010) also recorded highest incidence of red pumpkin beetle during 
Table 2: Seasonal incidence of insect pests and natural enemies of cucumber (Mean data of two years, 2014 and 2015)

\begin{tabular}{|c|c|c|c|c|c|c|c|c|c|}
\hline \multirow[t]{2}{*}{ Dates } & \multirow{2}{*}{$\begin{array}{l}\text { Standard } \\
\text { Week }\end{array}$} & \multicolumn{6}{|c|}{ Insect pests } & \multicolumn{2}{|c|}{ Natural enemies } \\
\hline & & $\begin{array}{c}\text { Red } \\
\text { pumpkin } \\
\text { beetle/ } \\
\text { plant }\end{array}$ & $\begin{array}{c}\text { Fruit fly/ } \\
\text { trap/ } \\
\text { week }\end{array}$ & $\begin{array}{c}\text { Epilachna } \\
\text { beetle/ } \\
\text { plant }\end{array}$ & $\begin{array}{c}\text { Whitefly/ } \\
3 \text { leaves/ } \\
\text { vine }\end{array}$ & $\begin{array}{l}\text { Leaf } \\
\text { roller/ } \\
\text { vine }\end{array}$ & $\begin{array}{c}\text { Leaf } \\
\text { miner/ } \\
\text { vine }\end{array}$ & $\begin{array}{c}\text { Coccinellids/ } \\
\text { vine }\end{array}$ & $\begin{array}{l}\text { Spiders/ } \\
\text { vine }\end{array}$ \\
\hline 26 Mar-01 Apr & $13^{\text {th }}$ & 0.80 & - & 0.30 & 1.40 & 0.20 & 0.60 & 0.33 & 0.50 \\
\hline 02 Apr-08 Apr & $14^{\text {th }}$ & 0.75 & - & 0.40 & 1.70 & 0.42 & 0.65 & 0.35 & 0.80 \\
\hline 09Apr-15 Apr & $15^{\text {th }}$ & 1.40 & - & 0.40 & 2.90 & 0.42 & 1.20 & 0.54 & 1.10 \\
\hline 16Apr-22 Apr & $16^{\text {th }}$ & 2.00 & 40.00 & 0.50 & 3.25 & 0.48 & 1.70 & 0.55 & 1.35 \\
\hline 23 Apr-29 Apr & $17^{\text {th }}$ & 2.10 & 40.50 & 0.75 & 4.00 & 0.65 & 3.30 & 0.54 & 1.60 \\
\hline 30 Apr-06 May & $18^{\text {th }}$ & 2.95 & 50.00 & 0.90 & 4.40 & 0.80 & 3.70 & 0.75 & 2.20 \\
\hline 07 Маy-13 Мay & $19^{\text {th }}$ & 3.40 & 56.00 & 0.78 & 4.55 & 0.78 & 4.20 & 0.71 & 2.55 \\
\hline 14 Мay-20 May & $20^{\text {th }}$ & 3.20 & 63.00 & 0.70 & 5.00 & 0.76 & 4.20 & 0.85 & 2.40 \\
\hline 21 Мay-27 May & $21^{\mathrm{st}}$ & 3.30 & 66.00 & 0.50 & 5.40 & 0.70 & 4.10 & 1.10 & 2.04 \\
\hline 28 May-03 Jun & $22^{\text {nd }}$ & 2.80 & 57.00 & 0.46 & 5.30 & 0.53 & 3.34 & 0.71 & 1.70 \\
\hline 04 Jun-10 Jun & $23^{\mathrm{rd}}$ & 1.90 & 54.00 & 0.40 & 4.10 & 0.37 & 3.00 & 0.55 & 1.35 \\
\hline 11 Jun-17 Jun & $24^{\text {th }}$ & 1.00 & 42.00 & 0.32 & 3.40 & 0.20 & 3.50 & 0.50 & 1.33 \\
\hline
\end{tabular}

Table 3: Correlation studies between insect pests and natural enemies of cucumber with weather parameters (Pooled value of two years)

\begin{tabular}{lllllll}
\hline Insect pests & $\begin{array}{l}\text { Maximum } \\
\text { temperature }\end{array}$ & $\begin{array}{l}\text { Minimum } \\
\text { temperature }\end{array}$ & $\begin{array}{l}\text { Maximum } \\
\text { R.H. }\end{array}$ & $\begin{array}{l}\text { Minimum } \\
\text { R.H. }\end{array}$ & Rainfall & $\begin{array}{l}\text { Sunshine } \\
\text { hours }\end{array}$ \\
\hline Melon fruit fly & $0.623^{*}$ & $0.632^{*}$ & -0.380 & -0.124 & -0.303 & 0.309 \\
Red pumpkin beetle & $0.550^{*}$ & $0.657^{*}$ & -0.298 & 0.015 & -0.452 & 0.262 \\
Epilachna beetle & 0.399 & $0.540^{*}$ & -0.332 & 0.176 & -0.228 & -0.050 \\
Whitefly & $0.554^{*}$ & $0.671^{*}$ & -0.380 & -0.080 & -0.448 & 0.392 \\
Pumpkin Caterpillar & 0.279 & 0.353 & -0.141 & -0.014 & -0.263 & 0.219 \\
Leafminer & $0.727^{*}$ & $0.843^{*}$ & -0.513 & -0.159 & -0.534 & 0.340 \\
Natural enemies & & & & & & \\
Coccinellids & $0.576^{*}$ & $0.630^{*}$ & -0.297 & -0.137 & -0.476 & 0.452 \\
Spiders & $0.590^{*}$ & $0.701^{*}$ & -0.311 & -0.0340 & -0.499 & 0.292 \\
\hline
\end{tabular}

* Correlation is significant at the 0.05 level of significance

summer season.A. foveicollis population had positive

in last week of April to third week of May with the population significant correlation with maximum $(\mathrm{r}=+0.550)$ and minimum $(\mathrm{r}=+0.657)$ temperature (Table 3 ), while maximum $\mathrm{RH}(\mathrm{r}=-0.298)$ and rainy days $(\mathrm{r}=-0.452)$ had non significant negative correlation with pumpkin beetle population.

\section{Epilachna beetle (Epilachna vigintioctopunctata, Fabricius)}

Epilachna beetle was initiated from last week of March to second week of June (Table 2). The population was highest of 0.70 to 0.90 beetles/plant. Significant positive correlations was obtained only with minimum temperature $(r=+0.540)$ while the positive correlations with maximum temperature $(\mathrm{r}$ $=+0.399)$ and negative correlation with maximum relative humidity $(r=-0.332)$ and rainfall $(r=-0.228)$ were non significant(Table 3$)$.

The results are in conformity with the findings of Barma and Jha (2013), about the incidence of epilachna beetle on pointed gourd which revealed that the significant 
Table 4: Correlation studies between spider and pest's

\begin{tabular}{ll}
\hline Pests & Spider \\
\hline Melon fruit fly & $0.865^{*}$ \\
Red pumpkin beetle & $0.951^{*}$ \\
Epilachna beetle & $0.805^{*}$ \\
Whitefly & $0.885^{*}$ \\
Pumpkin caterpillar & $0.867^{*}$ \\
Leafminer & $0.788^{*}$ \\
\hline
\end{tabular}

* Correlation is significant at the 0.05

positive correlation with maximum temperature and negative correlation to other remaining factors.

\section{Whitefly (Bemisia tabaci, Genn.)}

The peak incidence of whitefly was recorded during last week of May to second week of June (4.00 to 5.40/ 3 leaves/ vine) (Table 2). The correlation study showed that B. tabaci population had significant and positive correlation with maximum and minimum temperatures, whereas, it had negative correlation with relative humidity, rainfall (Table $3)$. The present findings are in agreement with Manoj and Anil (2016) who found that the correlation coefficient of B. tabaci population with different weather variables showed that Tmax and Tmin were significantly and positively correlated with B. tabaci population in all the varieties at 5 per cent level. Evening relative humidity (RHe) has significant but negative correlation with B. tabaci population. RHm,WS, SS and rainfall had non significant correlation with B. tabaci population.

\section{Pumpkin Caterpillar (Diaphania indica, Saunders)}

Pumpkin Caterpillar, Diaphania indica (Saunders) was recorded throughout the crop season in both the two years of study.Population was very low 0.20 to 0.80 per vine (Table 2) with the peak incidence during last week of April to last week of May( 0.65 to 0.80 larvae/vine).The maximum and minimum temperatures exerted positive correlations, whereas max. and min. relative humidity, rainfall had negative correlation with the pest population but all were non significant.Halder et al. (2017) found that the maximum, minimum and mean temperature, growing degree day and evaporation rate showed significant positive correlations with $\mathrm{D}$. indica, whereas a negative correlation was established with relative humidity, rainfall and wind velocity.

\section{Leaf miner (Liriomyza trifolii, Burgess)}

The leaf damage by L. trifolii was maximum (3.30 to 4.20 mines/ vine) during last week of April to third week of
May (Table 2). Aawathanarayana Reddy andAshok Kumar (2004) found that the peak infestation of leafminer was noticed during March - April.The highly significant positive correlations with maximum and minimum temperature $(\mathrm{r}=$ +0.727 and $\mathrm{r}=+0.843$ ) and non significant correlation with other weather parameters were obtained (Table 3 ).

\section{Coccinellids}

The population of coccinellids (Coccinella septempunctata L. and Menochilus sexmaculata Fabricius) ranged from 0.33 to 1.10 coccinellid/ vine with the peak incidence of coccinellids ( 0.71 to 1.10 coccinellids/ vine) during first week of May to first week of June (Table 2). The coccinellids also showed significant positive correlation with maximum $(\mathrm{r}=+0.576)$ and minimum $(\mathrm{r}=-0.630)$ temperature (Table 3). Meena and Shashi (2014) also found that maximum and minimum temperature and relative humidity showed significant positive correlation with coccinellids population.

\section{Spiders}

Analysis of pooled data on spider incidence for both the two years revealed that the predator was active throughout the growing season of cucumber. The important species of spider found dominated in the cucumber field are Neoscona spp and Oxyopes spp. Peak spider activity ( 1.60 to 2.55 spiders/ vine) was recorded during third week of April to last week of May (Table 2).Spider incidence had asignificant positive correlation with maximum $(\mathrm{r}=+0.590)$ and minimum temperature $(\mathrm{r}=+0.701)$ and non significant with other paramters. The present findings are accorded with Sunil (2013) who found that spiders incidence showed negative correlation with weekly total rainfall. This correlation indicated better activity of spider fauna at higher average temperature associated with relative humidity and low rainfall.

\section{Correlation between spider and pest's}

Spider had significant impact on the population of all insects viz: melon fruit fly, red pumpkin beetle, epilachna beetle, pumpkin caterpillar, whitefly and leaf miner (Table 4 ).

\section{CONCLUSION}

It is concluded that the population of fruit fly, B. cucurbitae, epilachna beetle, E. vigintiopunctata, red pumpkin beetle,A. foveicollis, pumpkin caterpillar, D. indica, whitefly, B. tabaci and leaf miner, L. trifolii of cucurbitaceous vegetables, were positively significantly influenced by 
maximum and minimum temperatures. Other weather parameters had non significant.

\section{ACKNOWLEDMENTS}

The authors would like to express their sincere thanksto Chairman, Department of Entomology and Associate Dean cum Principal of Bihar Agricultural College, Sabour for providing facilities to conduct studies.

\section{REFERENCES}

Aawathanarayana Reddy, N. and Ashok Kumar, C.T. (2004). Studies onthe seasonal incidence of insect pests of tomato inKarnataka. Pest Manag. Hort. Ecosyst., 2:113121.

Banerji, R., Sahoo, S. K., Das, S. K. and Jha, S. (2005). Studies onincidence of melon fly, Bactrocera cucurbitae (Coq.) in relation toweather parameters on bitter gourd in new alluvial zone of WestBengal. J. Entomol. Res. 29(3): 179-182.

Barma, P. and Jha, S. (2013). Insect and non insect pests infestingpointed gourd (Trichosanthes dioica Roxb.) in West Bengal. The Bioscan. 8(2): 537-543.

Halder, J. Deb, D. Kushwaha, Dand Rai,A.B. (2017). Effect of weather parameters on sporadic incidence of cucumber moth, Diaphania indica (Saunders) (Lepidoptera: Pyrallidae) in biitergourd ecosystem. J. Agrometeorol., 19(1): 67-70.
Khan, M.M.H., Alam, M.Z., Rahman, M.M., Miah, M.I.H. andHossain, M.M. (2012). Influence of weather factors on the incidenceand distribution of pumpkin beetle infesting cucurbits. Bangladesh J. Agril. Res. 37(2): 361-367.

Krishna Kumar, N. K., Verghese, A., Shivakumara, B., Krishnamoorthy,P. N. and Ranganath, H. R. (2006). Fruit Flies of Economic Importance.From basic to applied knowledge. In Proceedings of the $7^{\text {th }}$ International Symposium on Fruit Flies of Economic Importance, Salvador, Brazil.pp. 249-253.

Manoj, K. and Anil, G. (2016). Effect of weather variables on whitefly (Bemisia tabaci Gennadius) population indevelopment of potato apical leaf curl virus disease. $J$. Agrometeorol., 18(2): 288-291.

Meena, T. and Shashi, R. (2014). Effect of abiotic factors on population dynamics of insect pests and natural enemies in potato crop. J. Agrometeorol., 16(2): 187-191.

Rai, A. B., Halder, J. and Kodandram, M.H. (2014). Emerging insect pest problems in vegetable crops and their management in India: An appraisal. Pest Manag. Hort. Ecosyst., 20 (2): 113-122.

Rathod, S.T. and Borad, P.K. (2010). Population dynamics of redpumpkin beetle, Aulacophora foveicollis(Lucas) on pumpkin. Curr. Biotica. 3(4): 565-569.

Sunil, K.G. (2013). Harmful effect ofinsecticides in the population dynamics of spiders on okra Abelmoschus esculentus (L.) Moench at field level. American-EurasianJ. Agric. \& Environ. Sci., 13(9): 1181-1186. 